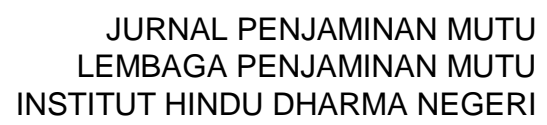

JURNAL PENJAMINAN MUTU

LEMBAGA PENJAMINAN MUTU

INSTITUT HINDU DHARMA NEGERI

DENPASAR
Volume 5 Nomor 2 Agustus 2019

ISSN : 2407-912X (Cetak)

ISSN : 2548-3110 (Online)

http://ejournal.ihdn.ac.id/index.php/JPM

\title{
EVALUATION OF QUALITY MANAGEMENT SYSTEM OF ISO 9001:2008 IN VOCATIONAL HIGH SCHOOLS
}

\author{
Oleh \\ Hendrina Widiastuty ${ }^{1}$, Sutarto Sutarto², Haryo Aji Pambudi \\ ${ }^{1}$ SMK Negeri 4 Solo \\ ${ }^{23}$ Universitas Negeri Yogyakarta \\ 1hendrina_smk4solo@yahoo.com, ${ }^{2}$ sutarto@uny.ac.id, ${ }^{3}$ haryoajipambudi@gmail.com
}

diterima 21 Mei 2019, direvisi 20 Agustus 2019, diterbitkan 31 Agustus 2019

\begin{abstract}
This research aims at evaluating the implementation of Quality Management System (QMS) of ISO 9001: 2008 in State Vocational High School 1 Surakarta and State Vocational High School 6 Surakarta through the Kirkpatrick model. The sample selection used the purposive sampling method with 77 teachers/staffs from the two schools. The data were collected with questionnaires and documentation. The implementation of QMS of ISO 9001: 2008 in both schools based on the input variables can be categorized as "very good with the score of 95 points out of 100 points. The results of the 3-behavior level evaluation on the QMS of ISO 9001: 2008 Implementation showed that the area of a) HR; b) the infrastructure; and c) the education process control and services in the State Vocational High School 1 and 6 Surakarta fell in the category of "mostly achieved". The results of a level 4 evaluation indicated the result of the graduates' quality in both schools can be categorized as good with the mean of 58.33. The QMS of ISO 9001: 2008 implementation proved to have a good effect on the school administration system in both schools where the granting of QMS of ISO 9001: 2008 certificates in line with the achievement of " $A$ " school accreditation over the past 10 years.
\end{abstract}

\section{Keywords: QMS of ISO 9001:2008, Kirkpatrick model, graduates' quality}

\section{INTRODUCTION}

The existence of a country can be seen from its ability to provide a major development in various aspects of peoples life. The nation progress is greatly determined by the education quality since it has a crucial role in realizing the national development goals. Education is expected to produce a generation who is strong, skilled, creative, innovative, imaginative, and sensitive to local wisdom and technoprenership [1] in order to be able to compete in the world of work.

One of the educational institutions that prepares students for the world of work is Vocational High School (VHS). This kind of 
schooling produces skilled individuals to work with certain competencies and to keep up with the development of science and technology. It considers as an inseparable part of the society development to improve the country's economy. As stated by Wilkins [2] that vocational education is a key factor in ensuring economic development, competitiveness, and social stability in all countries, either developing or industrialized ones.

As the main labor suppliers in the industry, vocational graduates are expected to have a good range of knowledge, skills, and personality to meet the expectations of the workforce and industry. However, the current conditions are very different from the expectation. Many graduates of vocational schools are unemployed, even those who already worked face many problems as found in the research results from Islami, et al. (2017).

One of the biggest factors causing the high unemployment rate is the people's mindset and attitude who still consider that a job as a permanent employee will ensure a better future compared to other jobs. This mindset has an impact on the lack of public interest in building and developing entrepreneurship. Only do a few people willing to create and develop their own job field.

In addition, unemployment is the result of low soft skills aspects among vocational school graduates. The soft has a relationship to build the working character which is needed by the industry. With this aspect, the graduates who can compete and be professional workers (Hartiningtyas, at all, 2016: 2). In other words, the fundamental problem is that the competence and expertise of vocational graduates do not meet the requirements as demanded by the industry or mismatch of skill required by the workforce. In line with this

Tom Karmel, et.al. (2008:7) mentions that if the match is very good, then we would conclude that the vocational education training (VET) system is performing its role in providing individuals with vocational skills. If the match is poor, then we need to think about whether the VET system is not as affective as it should be, or whether we should rethink the nature of vocational education.

The high unemployment rate of vocational graduates is often associated with the failure of the education system in producing graduates who ready to work. In fact, the state competitiveness depends on the knowledge and skills of its workforce. Arcaro, (1995:7) urges that the transformation to total quality school begins with the adoption of a shared dedication to the quality of the school board, administration, staff, students, parents, and the community. The process begins with the development of quality vision and mission of the district and for each school and department within the district.

It means that school management should create conditions that are more likely to achieve their goals. Managing educational organizations effectively or called Total Quality Management (TQM) is needed to accelerate the availability of superior human resources. It is a qualified management system to create organizational excellence. As described by Sallis (2002:25), TQM is a strategic approach to running an organization that focuses on the needs of its customers and clients. It rejects any outcome other than excellence.

The implementation of TQM) in schools can improve the quality of products or services to customers, because the service concept they hold is good enough is never good enough (Sutarto, 2015: 10). ISO 9001: 2008 Quality Management System (QMS) is one form of TQM concept implementation that is detailed and systematic in its application, built on the foundations of policies that are documented and carried out consistently. There is also periodic internal quality control.

The quality Management System (QMS) of ISO 9001: 2008 is one of the systems implemented by schools in developing their management benefits. It is in line with Law No. 20 of 2003 concerning National 
Education System Article 51 paragraph 1 that the management of secondary education units is carried out based on minimum service standards with the principle of School-Based Management (SBM). The implementation of QMS of ISO 9001: 2008 in schools is expected to be able to improve the quality of education-oriented in the process instead of input-oriented. The QMS of ISO 9001: 2008 aims to improve all school performances (effectiveness, quality, efficiency, innovation, relevance, and equity and access to education) in accordance with government policies contained in the Minister of Education and Culture Regulation no. 28 The year 2016 on quality assurance in primary and secondary education. It refers to a systematic, integrated and sustainable mechanism to ensure that the entire process of education implementation based on the standards.

The ultimate goal of QMS of ISO 9001: 2008 in the education, including vocational schools, is to improve the quality of education in order to be able to compete in this global competition era. However, according to Umiarso and Gojali (2011: 137), the application of TQM in educational organizations, especially public schools, is not simple. It seems that the obstacles appearing in the working culture, teachers' performance and staffs.

The State Vocational High School 1 and 6 Surakarta are the examples that have implemented QMS of ISO 9001: 2008 since 2008 and Surakarta Vocational High School 1 in 2011 until now. The preliminary observations in both schools indicated that the absorption percentage of graduates in industry, further study and entrepreneurship in the past three years still showed an up and down trend.

In addition, from the data of customer satisfaction recapitulation there are still some things that require special attention, such as 1) many students admit to having low-quality learning experiences, because learning relies more on the teacher-centered; and 2) the amount of infrastructure in theoretical classrooms and practice space is inadequate because many LCDs are damaged and computers often get an error.

It can be concluded that one of the efforts made by schools to improve the education quality in a sustainable manner is by implementing QMS of ISO 9001: 2008. This is crucial to clarify its effectiveness through evaluation of the QMS of ISO 9001: 2008 Implementation in State Vocational High Schools 1 Surakarta and 6 Surakarta.

\section{METHOD}

This research can be categorized as evaluation with quantitative descriptive using Kirkpatrick's level 3 - behavior and Level 4 Results which aimed to evaluate the implementation of the QMS of ISO 9001: 2008 in State Vocational High School 1 and 6 Surakarta. Evaluation of level 3 - Behavior in the implementation of the QMS of ISO 9001: 2008 was emphasized in behavioral assessment in work behavior of school citizens towards performance progress in their respective work units as seen from the implementation of the QMS of ISO 9001: 2008 in the field of human resources, infrastructure, the education process control and services.

Meanwhile the Level 4 - Results Evaluation was focused on the final result of the QMS of ISO 9001: 2008 implementation by clarifying the absorption percentage of the 0 years waiting period with indicators: 1) working in the industry; 2) pursuing education to Higher Education, and 3) creating entrepreneurship in the academic year of 2016/2017. It also examined the national exam results. To find out the impact of the QMS of ISO 9001: 2008 implementation of the quality of graduates, the quality data of graduates were examined before and after the ISO implementation.

The sample selection in this evaluation was purposive sampling according to the involvement of QMS of ISO 9001: 2008 implementation and graduate affairs. The respondents in this evaluation were the teachers and the staffs who received additional duty as the school management team. They were1) the representative of 
Quality assurance; 2) the deputy principal of the curriculum; 3) the deputy principal for student affairs; 4) the deputy of Infrastructure and workforce; 5) the deputy principal of public relations; 6) the head of the expertise competency; 7) the coordinator of normative teacher; 8) the coordinator of adaptive teacher; 9) the coordinator of carrier development and staff; 10) the deputy principal staff; 11) the team of QMS of ISO; 12) the counseling coordinator; 13) the head of the library; 14) head of lab or workshop; 15) the head of administration; and 16) the productive subject teachers (Accounting, Office Administration and Marketing) in State Vocational High School 1 and 6 Surakarta with the total of 77 persons.

The instruments used questionnaires and documentation. The questionnaire items were closed-ended questions with Linkert scale of four possible answers or statements totaling 108 items. The value of the answer was $1,2,3$ and 4 . The questionnaire was arranged based on the dimensions of QMS of ISO 9001: 2008 related to human resources, infrastructure, and control of the education process, facilities and services. Meanwhile, documentation was to collect data on input and results. The input variables included HR, facilities, and curriculum. The HR variable component consisted of teacher qualifications, including a) teachers' number, b) teacher education, and c) number of teachers with certification. It also involved the qualifications of administrative staffs, such as a) educational background, b) staff number. The variable components of infrastructure, including a) classrooms, b) general learning facilities, and c) supporting facilities. The result variable was the graduates' quality in case of working absorption and national examination scores. The graduates' absorption includes: a) working in industries, b) perusing to higher education, and c) being an entrepreneur. The national exam scores contained a) the average score of the National Examination for Indonesian Language, Mathematics, English, and b) the average score of the Productive National Examination.
Expert judgment was used to test the content validity by examining and evaluating the instrument systematically whether the items of the instrument have represented what they want to measure (Sugiyono, 2010: 177). This expert judgment was made by the lecturers of the Graduate program. The evaluation results from these experts served as guidelines for instrument improvement.

Validity testing on each item analysis correlates the value of each item with the total value (Sugiyono, 2010: 187) by using Bivariate Pearson correlation (Pearson Moment Products). If $r$ count $>r$ table, the item was considered valid. If $r$ counts $<r$ table, then the item was invalid. The size of the $r$ table was determined by the sample number. The questionnaire $\mathrm{OF}$ the QMS of ISO implementation was 77 with the significance level of $5 \%$, the $\mathrm{r}$ table was 0.224 (Sugiyono, 2012: 455).

The instrument reliability testing was done by Cronbach Alpha formula. The criteria to determine the reliability of the instrument were based on the value interpretation of the reliability coefficient. The obtained data described using descriptive statistics. In each level of evaluation, the variables in this study were considered appropriate if they meet the requirements and cover the indicator area.

\section{RESULTS AND DISCUSSION}

The results of data and documentation analysis of QMS of ISO 9001: 2008 Implementation in State Vocational High School 1 and 6 Surakarta based on: a) Input variable consisted of HR variables and infrastructure facilities; b) behavior variable (behavior) in the field of human resources, infrastructure, and the field of control of the education process and service provision, and c) result variable (outcome): the graduate quality, namely the graduates' absorption and national exam scores as follows:

Input variables consisted of HR variables and infrastructure. The HR variable component involved 2 (two) dimensions, namely teacher qualifications and administrative staff qualifications. The dimensions of teacher qualification had 3 
indicators i.e. a) The comparable number between teachers and students, b) teachers' education, and c) teachers' certification. Meanwhile, the qualifications dimensions of administrative staffs contained staffs' education and the number of personnel. Furthermore, the variable components of infrastructure were the qualifications of facilities that had three indicators, namely a) number of classrooms, b) general learning facilities, and c) the supporting facilities.

The application of the QMS of ISO 9001: 2008 based on input variables can be categorized as "very good" with the score of 91.69\% in State Vocational High School 1 Surakarta and $93.97 \%$ for State Vocational High School 6 Surakarta, respectively. It can be seen by the indicators accomplishment in the following table:

Table 1. The scores for Input Variable (HR) in VHS 1 and VHS 6 Surakarta

\begin{tabular}{|c|c|c|c|c|}
\hline & \multirow{2}{*}{ Indicator } & \multicolumn{2}{|c|}{ Achievement } & \multirow{2}{*}{ - Category } \\
\hline & & VHS 1 & VHS 6 & \\
\hline \multirow[t]{2}{*}{1} & \multirow{2}{*}{$\begin{array}{l}\text { Teacher } \\
\text { number }\end{array}$} & $65: 833$ & 93:1339 & \multirow[t]{2}{*}{ Fulfilled } \\
\hline & & $1: 13$ & $1: 15$ & \\
\hline 2 & $\begin{array}{l}\text { Teachers' } \\
\text { education }\end{array}$ & $100 \%$ & $100 \%$ & $\begin{array}{l}\text { Very } \\
\text { Good }\end{array}$ \\
\hline 3 & $\begin{array}{l}\text { Teacher } \\
\text { certification }\end{array}$ & $\begin{array}{c}58,46 \\
\%\end{array}$ & $\begin{array}{c}69,89 \\
\%\end{array}$ & Good \\
\hline 4 & $\begin{array}{l}\text { Administrati } \\
\text { ve staffs }\end{array}$ & $100 \%$ & $100 \%$ & Fulfilled \\
\hline 5 & $\begin{array}{l}\text { Number of } \\
\text { staffs }\end{array}$ & $100 \%$ & $100 \%$ & Fulfilled \\
\hline & Total & 91,69 & 93,97 & Fulfilled \\
\hline
\end{tabular}

Table 2. The scores for Input Variable (Infrastructure) in VHS 1 and VHS 6 Surakarta

\begin{tabular}{llccl}
\hline \multirow{2}{*}{ Indicator } & \multicolumn{2}{c}{ Achievement } & Category \\
\cline { 2 - 3 } & VHS 1 & VHS 6 & \\
\hline 1 & $\begin{array}{l}\text { Number of } \\
\text { classrooms }\end{array}$ & $\begin{array}{c}107,69 \\
\%\end{array}$ & $75,6 \%$ & Fulfilled \\
2 & $\begin{array}{l}\text { General } \\
\text { learning } \\
\text { facility }\end{array}$ & $100 \%$ & $100 \%$ & Fulfilled \\
3 & $\begin{array}{l}\text { Supporting } \\
\text { facility }\end{array}$ & $100 \%$ & $100 \%$ & Fulfilled \\
& Score & 100 & 91.87 & Fulfilled \\
\hline
\end{tabular}

The behavior variable consisted of three components, namely: 1) the QMS of ISO 9001: 2008 implementation in the field of human resources, 2) in the field of infrastructure, and 3) in the field of education process control and service provision.

The QMS of ISO 9001: 2008 implementation in the field of HR at State Vocational High School 1 and 6 Surakarta with 77 respondents/ employees was measured by a closed questionnaire containing 4 answer choices with the Likert scale model. It had 26 questions or statements consisting of five indicators, the mean of each indicator presented in the following table:

Table 3. The mean of each indicator for QMS of ISO 9001: 2008 implementation in the field of HR in VHS 1 and VHS 6 Surakarta

\begin{tabular}{|c|c|c|c|}
\hline \multicolumn{2}{|r|}{ Explanation } & \multirow{2}{*}{$\begin{array}{l}\text { VHS 1 } \\
83.30\end{array}$} & \multirow{2}{*}{$\begin{array}{l}\text { VHS 6 } \\
84.35\end{array}$} \\
\hline 1 & Mean score $(\mathrm{X})$ & & \\
\hline 2 & Minimum scores & 65 & 70 \\
\hline 3 & Maximum scores & 94 & 93 \\
\hline 4 & Standard Deviation & 8.12 & 5.46 \\
\hline 5 & HR input & 95 & 95 \\
\hline 6 & Percentage $(\%)$ & 80.09 & 81.11 \\
\hline 7 & $\begin{array}{l}\text { Accomplishment } \\
\text { Category }\end{array}$ & $\begin{array}{c}\text { Mostly } \\
\text { achieved }\end{array}$ & $\begin{array}{l}\text { Mostly } \\
\text { achieved }\end{array}$ \\
\hline 8 & \multicolumn{3}{|c|}{$\begin{array}{l}\text { The mean of each indicator for QMS of ISO } \\
\text { 9001: } 2008 \text { implementation in the field of HR }\end{array}$} \\
\hline $\mathrm{a}$ & $\begin{array}{l}\text { Determination of } \\
\text { competencies by } \\
\text { personnel according } \\
\text { to organizational } \\
\text { requirements }\end{array}$ & 35.22 & 35.85 \\
\hline $\mathrm{b}$ & $\begin{array}{l}\text { Education and } \\
\text { training }\end{array}$ & 12.84 & 12.50 \\
\hline $\mathrm{c}$ & Training evaluation & 15.78 & 16.45 \\
\hline $\mathrm{d}$ & $\begin{array}{l}\text { Awareness in } \\
\text { improving } \\
\text { competencies }\end{array}$ & 10.03 & 9.75 \\
\hline e & $\begin{array}{l}\text { The records of } \\
\text { training, skills and } \\
\text { experience }\end{array}$ & 9.43 & 9.80 \\
\hline
\end{tabular}

Based on Table 3 above, the mean score of the QMS of ISO 9001: 2008 implementation in the field of HR in State Vocational High School 1 Surakarta for the behavioral variable was 83.30 and indicated 
the of "mostly achieved" level. Likewise, with the score of 84.35 for Vocational High School 6 Surakarta that came into "mostly achieved" level.

The QMS of ISO 9001: 2008 implementation in the field of Infrastructure in the State Vocational High School 1 and 6 Surakarta with 77 respondents/ employees was measured by a closed questionnaire containing 4 answer choices with the Likert scale model. It had 26 questions or statements consisting of five indicators, the mean of each indicator presented in the following table:

Table 4. The mean of each indicator for QMS of ISO 9001: 2008 implementation in the field of Infrastructure in VHS 1 and VHS 6 Surakarta

\begin{tabular}{llcc}
\hline & Explanation & VHS 1 & VHS 6 \\
\hline 1 & Mean score (X) & 80.86 & 85.42 \\
2 & Minimum scores & 60 & 73 \\
3 & Maximum scores & 97 & 97 \\
4 & Standard Deviation & 10.24 & 6.86 \\
5 & Infrastructure input & 100 & 100 \\
6 & Percentage (\%) & 74.87 & 79.10 \\
7 & Accomplishment & $\begin{array}{c}\text { Mostly } \\
\text { achieved }\end{array}$ & $\begin{array}{c}\text { Mostly } \\
\text { achieved }\end{array}$
\end{tabular}

8 The mean of each indicator for QMS of ISO 9001:2008 in infrastructure field:

$\begin{array}{llll}\text { a Determination of } & 22.97 & 24.32\end{array}$ infrastructure facilities to support the educational process

b Provision of $48.81 \quad 51.18$ infrastructure facilities to support the educational process

c Maintenance of 9.08 9.92

infrastructure facilities to support the educational process

Based on Table 3 above, the mean score of the QMS of ISO 9001: 2008 implementation in the field of HR in State Vocational High School 1 Surakarta for the behavioral variable was 80.86 and indicated the of "mostly achieved" level. Likewise, with the score of 85.42 for Vocational High School 6 Surakarta that came into "mostly achieved" level.
In case of educational process control and service, it had 48 questions or statements consisting of five indicators, the mean of each indicator presented in the following table:

Table 5. The mean of each indicator for QMS of ISO 9001: 2008 implementation in the field of educational process control and service in VHS 1 and VHS 6 Surakarta

\begin{tabular}{clcc}
\hline & Explanation & VHS 1 & VHS 6 \\
\hline 1 & Mean score (X) & 149,16 & 153,42 \\
2 & Minimum scores & 117 & 134 \\
3 & Maximum scores & 173 & 180 \\
4 & Standard Deviation & 12,648 & 12,514 \\
5 & Percentage (\%) & 77,69 & 79,91 \\
6 & Accomplishment & $\begin{array}{c}\text { Mostly } \\
\text { achieved }\end{array}$ & $\begin{array}{c}\text { Mostly } \\
\text { achieved }\end{array}$
\end{tabular}

The mean of each indicator for QMS of ISO

7 9001:2008 in educational process control and service field:

a Information on $\quad 31,82 \quad 31,58$ the characteristics of the educational process

b Planning the $31,18 \quad 32,05$ education process based on Instructions

c Implementation 30,97 32,45 of the education process based on instructions

d Educational $\quad 12,57$ services

e Monitoring and 35,00 measurement

f Graduates $\quad 8,78 \quad 9,50$
activities

Based on Table 3 above, the mean score of the QMS of ISO 9001: 2008 implementation in the field of educational process control and service in the State Vocational High School 1 Surakarta for the behavioral variable was 149.16 and indicated the of "mostly achieved" level.

The level 4 evaluation of QMS of ISO 9001: 2008 emphasized on it, i.e. The graduates' quality. According to the Ministry of National Education (2003: 3), the success of graduates can be viewed 
from 1) the appropriateness between the graduates' work and their fields of expertise, 2) the period to have work maximum one year, 3) the graduates' absorption at least $75 \%$, and 5) $5 \%$ of the total graduates being entrepreneur.

The variable component of graduate quality included two dimensions, namely: a) the absorption of graduates, and b) the achievement of national exam scores. The results of the absorption analysis were in the academic year of 2016/2017 in State Vocational High School 16 Surakarta as presented in the following table:

Table 6 . The graduate quality in the academic

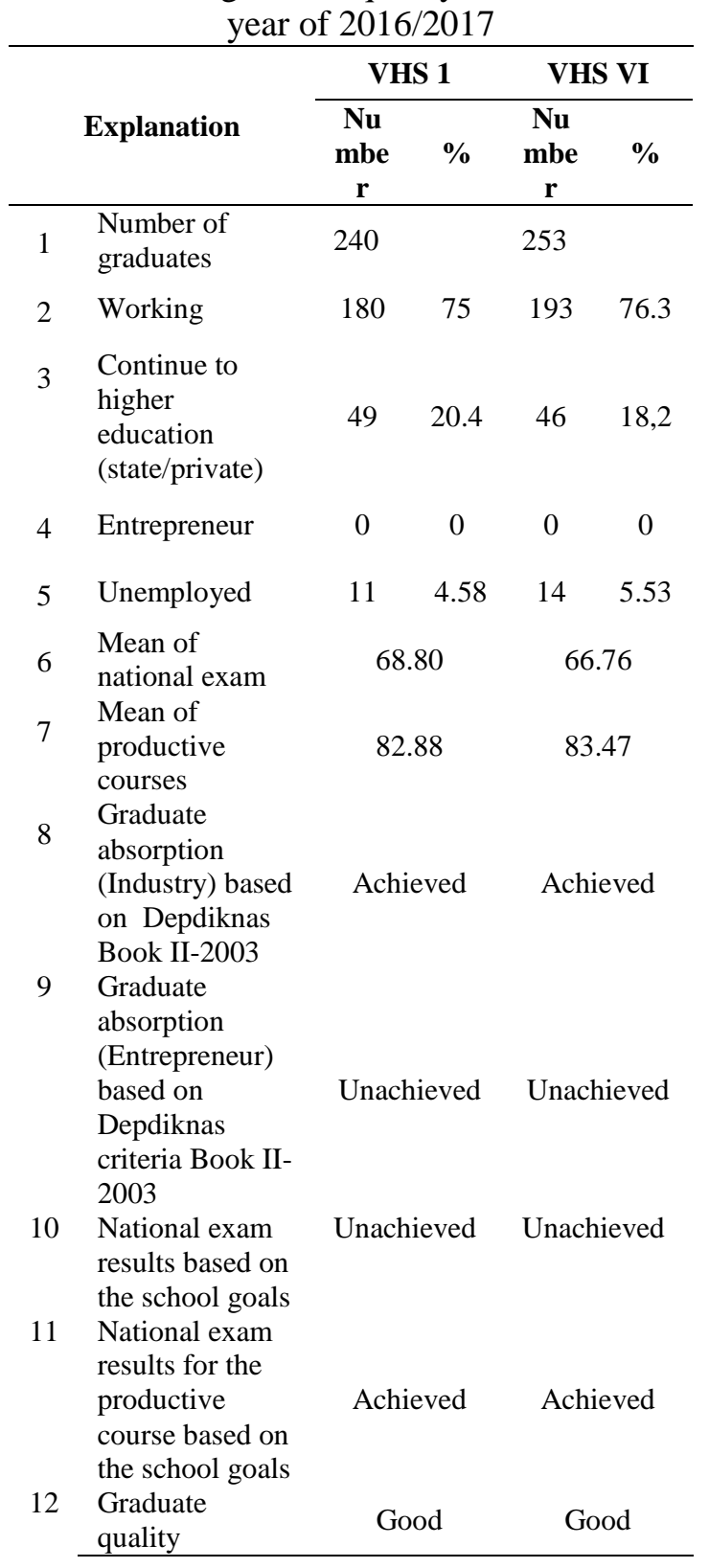

The evaluation results of the QMS of ISO 9001: 2008 implementation in the field of educational process control and services, showed that the mean results in the academic year of 2016/2017 Indonesian, English, and mathematics subjects had not yet achieved the school's target. The Implementation of ISO 9001 used the process approach, and the systematic approach as well as Plan - Do Check - Action (PDCA) pattern (Suryatama 2014: 29). It means that the output was not in line with the objectives, evaluation/ supervision must be done immediately by the principal as the top management in order to improve the learning outcomes. It has been highlighted by Klotz, et al (2014:1) that Vocational learning comprises more than factual knowledge and procedures; the development of a vocational identity is a key aspect and outcome of vocational education provisions and assumed to play an integral role in how students learn and perform. In line with this, Bradley (1994:12) mentioned that in teaching and learning activities, teachers should look themselves as class leaders by emphasizing quality through noncoercive management that displays students as workers and teachers as trainers as well as directing students how to learn and teach it to others.

To find out the impact of the QMS of ISO 9001: 2008 implementation of the quality of graduates, the following is presented the absorption data in the academic year of 2009/2010.

Table 7. The Graduate Data of State VHS Surakarta in the academic year of 2009/2010

\begin{tabular}{|c|c|c|c|c|c|}
\hline & \multirow{2}{*}{ Explanation } & \multicolumn{2}{|c|}{ VHS 1} & \multicolumn{2}{|c|}{ VHS 6} \\
\hline & & $\begin{array}{c}\text { Num } \\
\text { ber }\end{array}$ & $\%$ & $\begin{array}{c}\text { Num } \\
\text { ber }\end{array}$ & $\%$ \\
\hline 1 & $\begin{array}{l}\text { Number of } \\
\text { graduates }\end{array}$ & 230 & & 236 & \\
\hline 2 & Working & 166 & 72,2 & 116 & 49,2 \\
\hline 3 & $\begin{array}{l}\text { Continue to } \\
\text { higher } \\
\text { education } \\
\text { (state/private) }\end{array}$ & 38 & 16,5 & 35 & 14,8 \\
\hline 4 & Entrepreneur & 5 & 2,2 & 20 & 8,5 \\
\hline \multirow[t]{2}{*}{5} & Unemployed & 21 & 9,1 & 65 & 27,5 \\
\hline & Total & 230 & 100 & 236 & 100 \\
\hline
\end{tabular}


The year of 2009/2010 was the first year of the State Vocational High School 1 Surakarta in implementing ISO 9001: 2000. Meanwhile, for State Vocational High School 6 Surakarta, it was the 3rd year. Based on the analysis results in Table 6 and Table 7, there is an increase in the percentage of graduates absorption in the industry and a decrease for unemployed graduates between $2009 / 2010$ and 2016/2017. However, the percentage of graduates who were able to create their own jobs (entrepreneur) decreased.

The lack of graduates who were able to create their own employment indicated the weakness of entrepreneurship aspects in vocational students. In the vocational curriculum, entrepreneurship course was given for 3 years at 2 hours per week, but it had not been able to foster the students' willingness for being entrepreneurial. The efforts to develop an entrepreneurship aspect in their fields cannot be limited to theoretical learning in the classroom, but it was very necessary for real learning activities.

As stated by Zirkle, Christopher, and Lindsey Martin (2012:21) that vocational high schools are multifaceted disciplines, which offer many different opportunities for all students because the curricular approach provides various choices for students, in addition to the historical focus on preparation for beginner level work. Moreover, educators and policymakers seek to find ways to involve students in the class and production unit, so that students are expected to play a role in the business. Moreover, Zirkle C, et.al (2011:2), expresses that vocational education and training is responsive to both the demands for a flexible workforce while equipping individuals with broad-based skills and knowledge. Ab. Hadi, et al. (2015:1163) in his study found that learning in vocational schools was to produce workers that enable them to interact with work tasks in organizing workplaces.

The change in the spectrum of the 2013 curriculum made entrepreneurship course which was previously as adaptive subjects, now expanded to become creative and entrepreneurial subjects as well as belong to the C3 group. The school through the head of the Expertise Program is expected to encourage the growth of the vocational school graduates to create their own jobs.

The low percentage of graduates who are being an entrepreneur and the achievement of national exam scores indicate that the QMS of ISO 9001: 2008 implementation in State Vocational High School 1 and 6 Surakarta 1 has run in the category of mostly achieved but it has not been fully impacting to improve the graduates' quality of.

According to Komariah and Triatna, (2006:2), schools as a system consists of input, process, and output. The educational output is the focus of educational endeavors, but the most important thing is how to utilize these inputs related to individuals and other sources in the school.

The QMS of ISO implementation in schools, according to Usman (2016: 591), aims to improve customers' satisfaction by implementing the system effectively and efficiently, including the repair process if the process has not yet achieved the target and customer requirements. The results of the achievement for QMS of ISO 9001: 2008 implementation of School Implementation Systems in both schools presented in the following table:

Table 8. The QMS of ISO 9001:2008 on school implementation system in both schools

\begin{tabular}{|c|c|c|}
\hline \multirow{2}{*}{$\begin{array}{c}\text { The Component of } \\
\text { School Implementation } \\
\text { System } \\
\end{array}$} & \multicolumn{2}{|c|}{$\begin{array}{c}\text { Achievement of QMS of } \\
\text { ISO 9001:2008 }\end{array}$} \\
\hline & VHS I & VHS 6 \\
\hline \multicolumn{3}{|l|}{$\begin{array}{ll}1 & \text { Input } \\
& \text { a. HR }\end{array}$} \\
\hline $\begin{array}{l}\text { - Teachers' } \\
\text { qualification }\end{array}$ & Very Good & Very Good \\
\hline - Staffs' qualification & Very Good & Very Good \\
\hline b. Infrastructure & Very Good & Very Good \\
\hline $\begin{array}{l}\text { - Infrastructure } \\
\text { qualification }\end{array}$ & Very Good & Very Good \\
\hline \multicolumn{3}{|l|}{2 Process } \\
\hline $\begin{array}{l}\text { a. QMS of ISO } \\
\text { implementation of } \\
\text { HR }\end{array}$ & $\begin{array}{l}\text { Mostly } \\
\text { achieved }\end{array}$ & $\begin{array}{l}\text { Mostly } \\
\text { achieved }\end{array}$ \\
\hline $\begin{array}{l}\text { b. QMS of ISO } \\
\text { implementation for } \\
\text { Infrastructure }\end{array}$ & $\begin{array}{l}\text { Mostly } \\
\text { achieved }\end{array}$ & $\begin{array}{l}\text { Mostly } \\
\text { achieved }\end{array}$ \\
\hline $\begin{array}{l}\text { c. QMS of ISO } \\
\text { implementation for } \\
\text { educational process }\end{array}$ & $\begin{array}{l}\text { Mostly } \\
\text { achieved }\end{array}$ & $\begin{array}{l}\text { Mostly } \\
\text { achieved }\end{array}$ \\
\hline
\end{tabular}




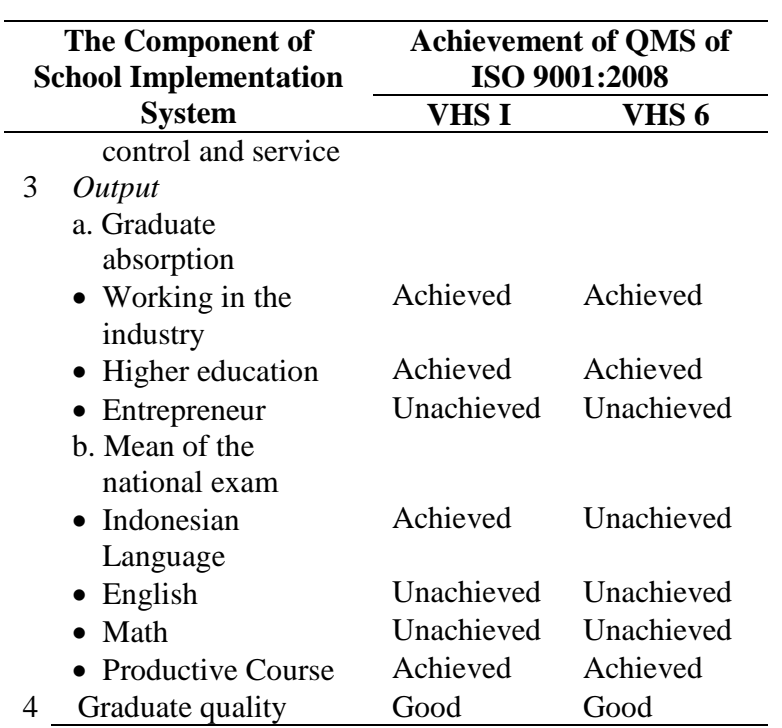

Based on the achievement data on the QMS of ISO 9001: 2008 implementation in the field of human resources, infrastructure, the educational process control and services in the State Vocational High School 1 and 6 Surakarta, the input component can be categorized as "very good". Besides, the process of implementing a QMS of ISO 9001: 2008 in the field of human resources, infrastructure, the field of educational process control and services can be categorized as "mostly achieved".

In the output variable, the achievement of graduates' absorption had not reached $100 \%$ (around 66\%) from the criteria set by the Ministry of National Education in the Book II of 2003. In details, the graduates who create their own jobs (entrepreneurship) is still $0 \%$. Also, the achievement of the national examination average in Indonesian, English, and math course was around $25 \%$ of the school target. On the other hand, the target of the national exam for the productive course has been achieved.

Related to this finding, Usman (2016: 543) clarifies that educational inputs are considered as high quality if it is ready to process. The process of qualified education can create a learning atmosphere that Active, Creative, Fun, and Meaningful - PAKEMB. Meanwhile, the output is good if the results of students' academic and non-academic are high. The outcome aspect can be said as qualified when graduates can be absorbed in time with fair salaries and the employers are satisfied with the graduates' performance. Related to this, Wani, et al (2014: 73) revealed that total quality management in education cannot be achieved without a commitment from everyone in the organization, from top to the bottom management. In this case, the school quality is influenced by many stages of interconnected activities (processes) such as planning, implementation, and supervision

According to Usman (2016), organizations or schools that have implemented QMS of ISO 9001: 2008 and have obtained ISO 9001: 2008 certificates should have carried out evaluations. The QMS of ISO 9001: 2008 document control is a key element in the implementation. Without the document control (quality guidelines, procedures, work instructions, and supporting forms) as well as accurate and complete records, the organization will fail to obtain an ISO certificate of 9001: 2008.

Based on the above results, it can be concluded that the QMS of ISO 9001: 2008 implementation in State Vocational High School 1 and 6 Surakarta has been well implemented and proven to improve the quality of the school administration system. This is evidenced by the acquisition of QMS of ISO 9001: 2008 certificates from the quality assurance system and " $A$ " accreditation for both schools in the past 10 years.

\section{CONCLUSION}

Based on the analysis results and discussion regarding the evaluation of the QMS of ISO 9001: 2008 implementation in State Vocational High School 1 and 6 Surakarta, some conclusion can be drawn as follows. The implementation of QMS of ISO 9001: 2008 in both schools based on the input variables can be categorized as "very good with the score of 95 points out of 100 points. The results of the 3-behavior level evaluation on the QMS of ISO 9001: 2008 Implementation showed that the area of a) HR; b) the infrastructure; and c) the education process control and services in the State Vocational High School 1 and 6 Surakarta fell in the category of "mostly achieved". The results of a level 4 evaluation indicated the result of the graduates' quality in both schools can be 
categorized as good with the mean of 58.33. The QMS of ISO 9001: 2008 implementation proved to have a good effect on the school administration system in both schools where the granting of QMS of ISO 9001: 2008 certificates in line with the achievement of "A" school accreditation over the past 10 years.

\section{REFERENCES}

Ab.Hadi, M. Y., Hassan, R., Razzaq, A. R. A., Mustafa, M. Application of thinking skills in career: "A Survey on Technical and Vocational Education Training (TVET) qualification semiprofessional job duties.

Amin, M. M., Strategi Implementasi Revitalisasi SMK "10 Langkah Revitalisasi SMK" Jakarta: Direktorat Pembinaan Sekolah Menengah Kejuruan, 2017, pp. 1-8.

Arcaro, J. S. "Quality in Education "An Implementation Handbook". Florida: St. Lucie Press. 1995, pp.6-10.

Bradley, L. H. "Total Quality Management for Schools".1994. R\&L Education.

Catts, R., Falk. I., and Wallace. R. Vocational Learning "Innovative Theory and Practice". Springer Science \& Business Media. 2011.

Hartiningtas, L., Purnomo, Elmunsyah, H., dan Nurmalasari., R. Correlation between creative thinking skill and competency achievement with vocational maturity on vocational high school. AIP Conference Proceedings. Vol. 1778 (1). p1-7. DOI: 10.1063/1.4965766). 2016.

Husaini, U. "Manajemen. Teori, Praktik, dan Riset Pendidikan". Edisi 4. Jakarta: PT. Bumi Aksara. 2016, pp. 543-555

Islami, P. A. F., Elmunsyah, H., and Muladi. (2017). Contribution entrepreneurial knowledge, skills competence, and self-efficacy to student entrepreneurship readiness of multimedia expertise at vocational high school in Malang. AIP Conference Proceedings Vol. 1887 (1). p1-11. DOI: 10.1063/1.5003535.
Karmel, T., Mlotkowski, P., \& Awodeyi, T. (2008). Is VET Vocational? The Relevance of Training to the Occupations of Vocational Education and Training Graduates. Australia: National Centre for Vocational Education Research.

Klotz, V. K., Billett. S., and Winther.S. Promoting workforce excellence: formation and relevance of vocational identity for vocational educational training. Empirical Research in Vocational Education and Training 2014, 6 (6).

Salis. E. "Total Quality Management in Education". London: Kogan page limited. Third edition. 2002, pp. 22-26.

Sugiyono. "Metode Penelitian Pendidikan "Pendekatan Kuantitatif, Kualitatif dan R\&D”. Bandung: Penerbit Alfabeta.2010, pp. 177-187.

Sutarto. "Manajemen Mutu Terpadu (MMTTQM)". Yogyakarta: UNY Press. 2015, pp. 9-10.

Suryatama, E. "Aplikasi ISO Sebagai Standar Mutu". Kata Pena. 2014, pp. 29-30

Umiarso, dan Gojali. I. "Manajemen Mutu Sekolah di Era Otonomi Pendidikan". Yogyakarta: IRCiSoD. 2011, pp. 133137.

Wani, Iftikhaar A. \& Mehraj, H. K. (2014). Total Quality Management in Education: An Analysis. International Journal of Humanities and Social Science InventionVolume 3(6), pp. 73.

Wilkins, Stephen, Human resource development through vocational education in the United Arab Emirates: the case of Dubai Polytechnic. Journal of Vocational Education \& Training. Vol. 54, No. 1. 2012.

Zirkle, C., and L, Martin. "Challenges and Opportunities for Technical and Vocational Education and Training (TVET) in the United States. M. Pilz (Ed.), The Future of Vocational Education and Training in a Changing World". 2012. DOI 10.1007/978-3531-18757-0_2. 